\title{
Pelatihan penyusunan laporan keuangan berdasarkan SAK ETAP dengan komputer pada koperasi Serba Usaha Mandiri, Desa Manisrenggo, Klaten
}

\author{
Wiwin Windihastuty*, Sri Rahayu, Krisna Adiyarta, \& Swasti Broto \\ Universitas Budi Luhur \\ *wiwin.windihastuty@budiluhur.ac.id
}

\begin{abstract}
Abstrak. Koperasi Serba Usaha Mandiri di Desa Manisrenggo, Kabupaten Klaten, Jawa Tengah telah menjalankan kegiatan intermediasi dengan mengumpulkan dana dari seluruh anggota koperasi dalam bentuk simpanan untuk kembali didistribusikan kepada anggota yang membutuhkan dana dalam bentuk pinjaman. Koperasi tersebut memiliki akuntabilitas publik yang signifikan, tetapi karena belum mendaftarkan diri sebagai perusahaan publik, maka Koperasi Serba Usaha Mandiri hanya bertanggung jawab atas dana anggota-anggotanya. Tujuan kegiatan Pengabdian kepada Masyarakat ini untuk meningkatkan kemampuan pengurus dalam menyusun laporan keuangan berdasarkan SAK ETAP baik secara manual maupun menggunakan sistem komputer. Kegiatan ini diawali dengan Introduction dan penyampaian materi laporan keuangan atau financial report berdasarkan SAK ETAP serta dilanjutkan dengan pelatihan pencatatan dengan menggunakan Excel. Materi yang disiapkan pada pelatihan ini meliputi proses penyusunan laporan keuangan yaitu pembuatan jurnal, buku besar, laporan neraca, laporan Sisa Hasil Usaha dan laporan arus kas. Setelah mengikuti peatihan, para pengurus koperasi Serba Usaha Mandiri telah bertambah pemahamannya tentang pentingnya penerapan SAK ETAP untuk menyajikan laporan keuangan Koperasi. Peningkatan pemahaman para pengurus koperasi mengenai konsep dan prinsip dasar akuntansi perkoperasian, unsur-unsur pengakuan, pengukuran dan penyajian laporan keuangan yang sesuai dengan SAK ETAP, dapat membantu mereka dalam proses penyusunan dan penyajian laporan keuangan pada periode yang akan datang.
\end{abstract}

Kata kunci: Koperasi, SAK ETAP, excel, intermediasi, distribusi

\begin{abstract}
Koperasi Usaha Mandiri in Manisrenggo, Klaten, Java has carried out intermediation activities by collecting funds from all cooperative members in form of savings to be distributed again to members who need funds in the form of loans. Koperasi has significant public accountability, but because it has not registered as a public company, Koperasi Usaha Mandiri is only responsible for the funds of its members. The purpose of this Community Service activity is to improve the management's ability to prepare financial reports based on SAK ETAP either manually or using a computer system. This activity begins with an introduction and submission of material on financial reports or financial reports based on SAK ETAP and is followed by training on recording using Excel. The material prepared in this training includes the process of preparing financial reports, namely making journals, ledgers, balance reports, reports on business results and cash flow reports. After attending the training, the management of the Koperasi has increased their understanding of the importance of implementing SAK ETAP to present cooperative financial reports. Increased understanding of cooperative management regarding the concepts and basic principles of cooperative accounting, elements of recognition, measurement and presentation of financial statements in accordance with SAK ETAP, can assist them in the process of preparing and presenting financial statements in future periods.
\end{abstract}

Keywords: koperasi, SAK ETAP, excel, intermediation, distribution

To cite this article: Windihastuty. W., S. Rahayu., K. Adiyarta., \& S. Broto. 2020. Pelatihan penyusunan laporan keuangan berdasarkan SAK ETAP dengan komputer pada koperasi Serba Usaha Mandiri, Desa Manisrenggo, Klaten. Unri Conference Series: Community Engagement 2: 153-158. https://doi.org/10.31258/unricsce.2.153-158

(C) 2020 Authors

Peer-review under responsibility of the organizing committee of Seminar Nasional Pemberdayaan Masyarakat 2020 


\section{PENDAHULUAN}

Koperasi merupakan badan usaha yang beranggotakan orang-orang atau badan hukum dengan melaksanakan kegiatannya berdasarkan prinsip koperasi sebagai gerakan ekonomi rakyat berdasarkan asas kekeluargaan. Koperasi bertujuan untuk meningkatkan kesejahteraan anggotanya untuk mencapai tujuan tersebut koperasi harus dikelola dengan baik agar dapat berkembang dan berkelanjutan. Agar usaha koperasi dapat berkembang dan berkelanjutan maka perlu diperhatikan usaha dalam mempertinggi tingkat efisien yaitu koperasi harus dapat menangani bidang-bidang usahanya dengan biaya atau pengeluaran yang seminimal mungkin, koperasi harus dapat mencegah terjadinya pemborosan-pemborosan. Informasi akuntansi mengenai biaya atau pengeluaran, modal, kewajiban, suatu koperasi dapat dilihat dalam laporan keuangan (Financial Report). Untuk itu pelatihan penyusunan laporan keuangan berdasarkan SAK ETAP sangat diperlukan sehingga laporan keuangan yang dibuat memenuhi berbagai pihak yang berkepentingan terhadap laporan keuangan untuk pengambilan keputusan. Melalui pelatihan ini pihak koperasi diharapkan akan dapat menyusun laporan keuangan berdasarkan SAK ETAP. Lebih lanjut dalam SAK tentang akuntansi perkoperasian dinyatakan bahwa bentuk penyajian laporan keuangan koperasi terdiri dari neraca, perhitungan hasil usaha, laporan arus kas, laporan promosi ekonomi anggota dan catatan atas laporan keuangan. Untuk penyajian neraca, komponenkomponennya terdiri dari aktiva, kewajiban dan ekuitas. Ekuitas terdiri dari simpanan wajib, simpanan pokok, modal penyertaan, modal sumbangan, cadangan dan sisa hasil usha (SHU) belum dibagi. Penerapan SAK ETAP dalam penyusunan laporan keuangan dilapangan terutama pada koperasi Serba Usaha Budi Luhur Mandiri di Desa Manisrenggo, Klaten yang mempunyai kegiatan usaha simpan pinjam belum sepenuhnya dapat dilaksanakan, hal ini disebabkan salah satunya karena faktor sumber daya manusia sebagai pengelola koperasi masih belum memahami akan penyusunan laporan keuangan koperasi berdasarkan SAK ETAP. Peta Wilayah Desa Manisrenggo, Kabupaten Klaten seperti pada Gambar 1 berikut ini:

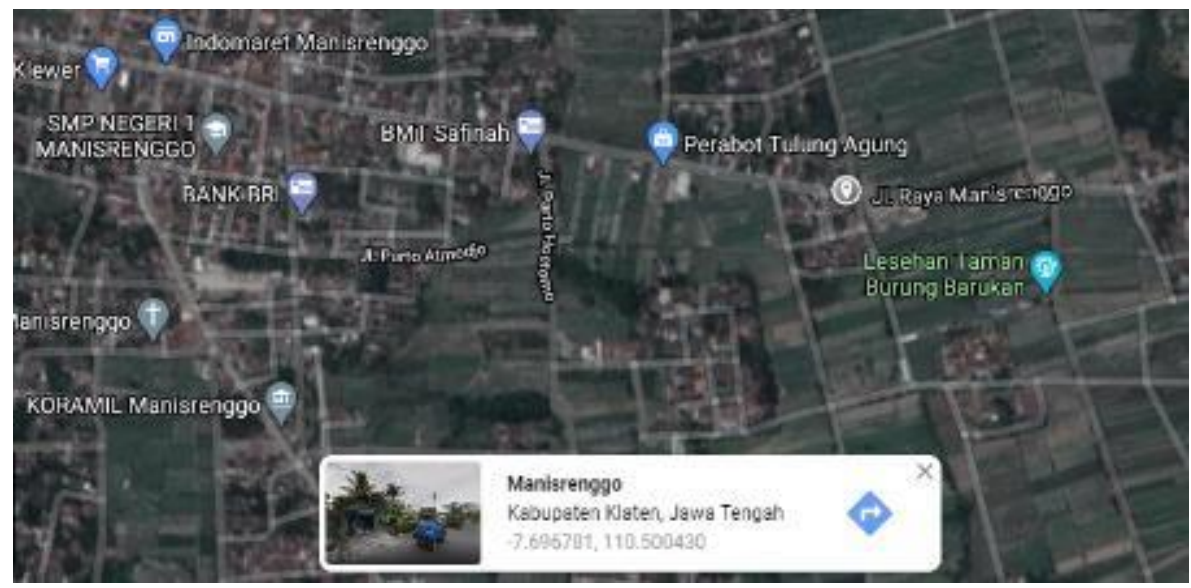

Gambar 1. Desa Manisrenggo, Klaten

Standar Akuntansi Keuangan untuk Entitas Tanpa Akuntabilitas Publik (SAK ETAP) yang berlaku saat ini wajib digunakan oleh entitas tanpa akuntabilitas publik termasuk koperasi. Namun sampai saat ini koperasi Serba Usaha Mandiri desa Manisrenggo, Klaten belum sepenuhnya dapat menerapkan SAK ETAP dalam penyusunan laporan keuangan, hal ini disebabkan salah satunya karena kurang mengertinya sumber daya manusia pengelola koperasi akan penyusunan laporan keuangan berdasarkan SAK ETAP. Secara rinci, permasalahan yang ingin dipecahkan dalam kegiatan Pengabdian Pada Masyarakat ini adalah apakah melalui pelatihan akan dapat meningkatkan kemampuan pengurus atau pengelola koperasi Serba Usaha Mandiri dalam menyusun laporan keuangan yang berdasarkan SAK ETAP baik secara manual maupun menggunakan sistem komputer. Tujuan kegiatan Pengabdian kepada Masyarakat ini adalah untuk meningkatkan kemampuan para pengurus atau pengelola koperasi Serba Usaha Mandiri desa Manisrenggo, Klaten dalam menyusun laporan keuangan berdasarkan SAK ETAP baik secara manual maupun menggunakan system computer. Manfaat langsung yang diharapkan dari kegiatan pengabdian masyarakat yang telah dilaksanakan ini adalah melalui pelatihan ini para pengurus atau pengelola koperasi Serba Usaha Budi Luhur Mandiri di Desa Manisrenggo, Klaten diharapkan akan dapat menyusun laporan keuangan yang berupa neraca, perhitungan Sisa hasil usaha dan laporan arus kas sesuai SAK ETAP baik secara manual maupun dengan menggunakan sistem Komputer, sehingga datanya lebih akurat. 


\section{METODE PENERAPAN}

Kegiatan pengabdian masyarakat ini berbentuk sosialisasi dan pelatihan mengenai pentingnya penyajian laporan keuangan koperasi yang sesuai dengan SAK ETAP yang dilakukan oleh tim pengurus koperasi Serba Usaha Budi Luhur Mandiri. Kegiatan dimulai dengan survey ke koperasi "Serba Usaha Mandiri", kemudian tim abdimas melakukan pengumpulan data keuangan dan menganalisis sejauh mana penerapan standar yang telah dilakukan oleh koperasi Serba Usaha Mandiri, dilanjutkan dengan sosialisasi mengenai SAK ETAP dan pentingnya penerapan standar tersebut sebagai pedoman penyajian laporan keuangan yang lebih akuntabel. Pelatihan ini dilakukan dengan berbagai metode kegiatan yang bervariasi, meliputi brainstorming mengenai permasalahan pencatatan keuangan dan pelaporannya. Sosialisasi tentang pentingnya penerapan SAK ETAP agar dapat menghasilkan informasi yang bermanfaat sebagai dasar pengambilan keputusan ekonomi yang tepat bagi para pengguna informasi keuangan koperasi, menjadi sesi utama dalam pembinaan ini. Pada sesi ini tim pengabdian masyarakat berusaha memberikan informasi menyeluruh mengenai hal tersebut diatas. Sosialisasi yang dilakukan tersebut disertai dengan diskusi dan tanya jawab.

\section{HASIL DAN KETERCAPAIAN SASARAN}

Sesuai dengan rencana yang telah ditentukan sebelum kegiatan pelatihan dilaksanakan, kegiatan ini diawali dengan penyiapan berbagai adiministrasi yang diperlukan antara lain permohonan ijin melaksanakan pengabdian masyarakat, undangan peserta pelatihan, koordinasi dengan pengurus Koperasi untuk waktu dan tempat pelatihan, penyiapan materi pelatihan tentang penyusunan laporan keuangan serta penyiapan Jadwal pelatihan. Berikut ini akan diuraikan hasil yang dicapai terkait dengan pelatihan penyusunan Financial Report berdasarkan SAK ETAP pada koperasi Serba Usaha Mandiri di Desa Manisrenggo, Klaten. Peserta yang hadir dalam pelatihan ini adalah sejumlah 8 orang peserta yang merupakan pengurus koperasi Serba Usaha Mandiri dan 3 orang dosen sebagai anggota tim pengabdian masyarakat. Foto-foto kegiatan seperti pada Gambar 2 berikut:
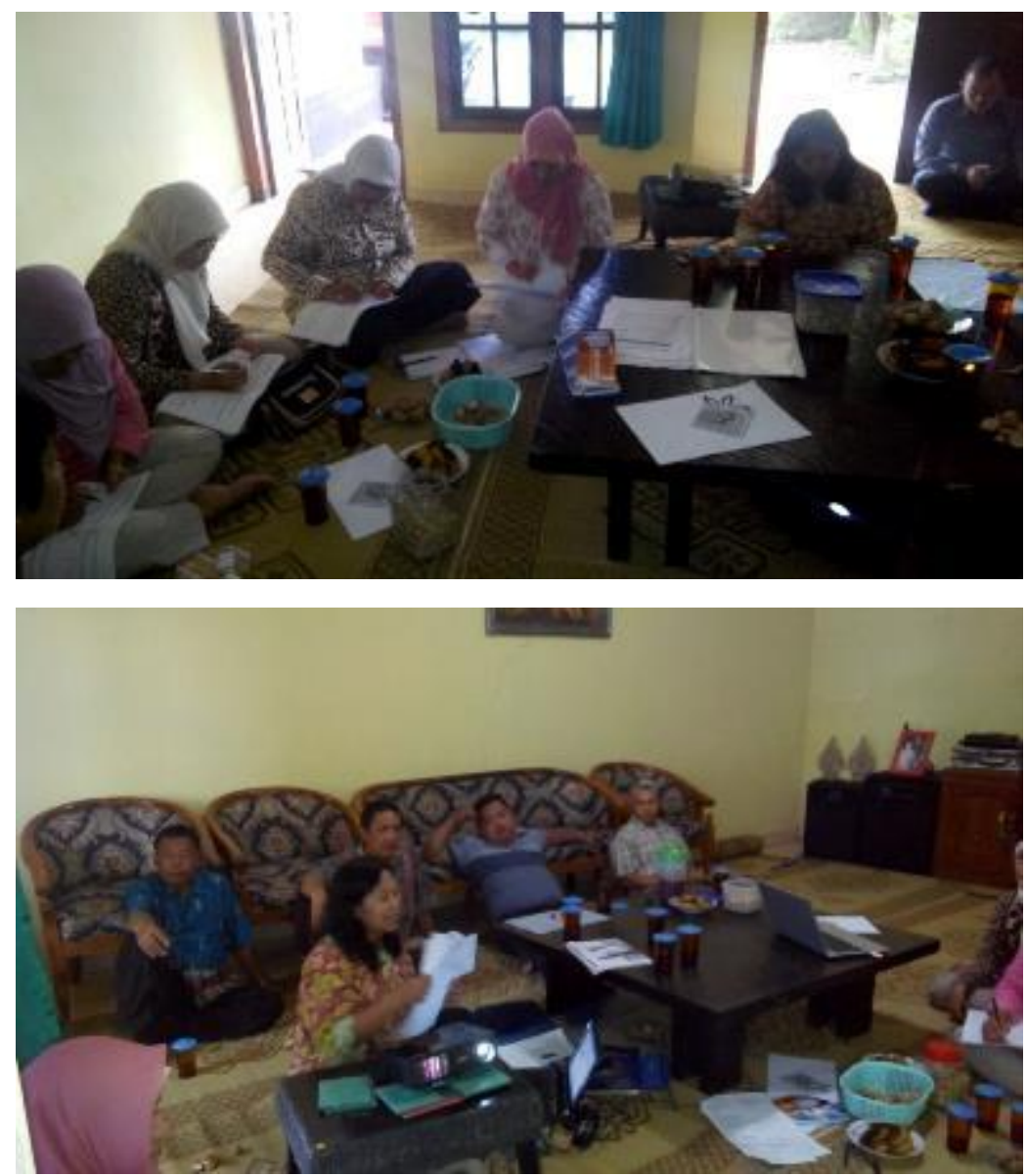


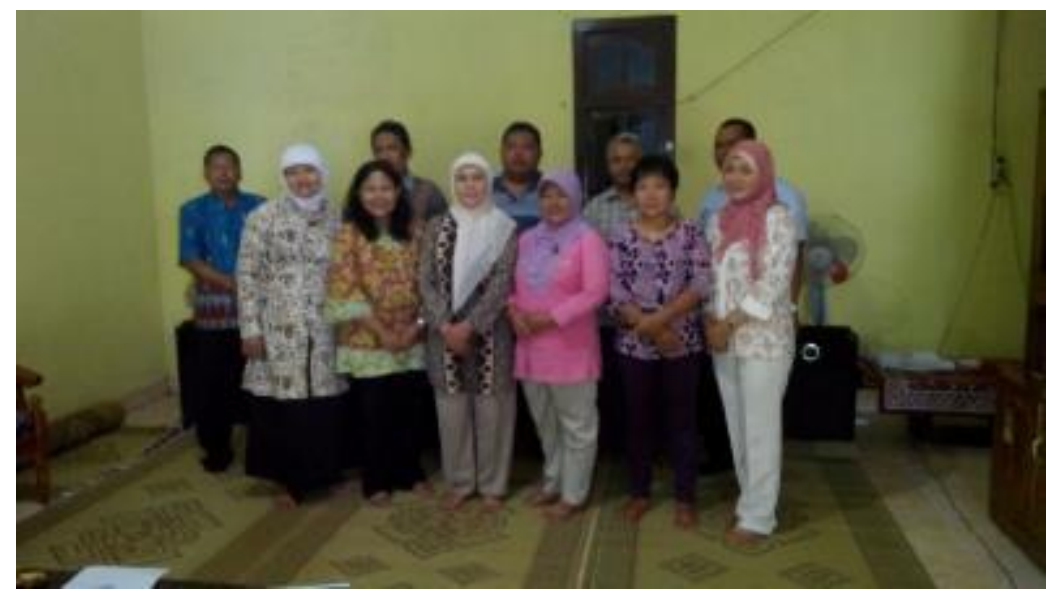

Gambar 2. Foto Kegiatan

Kegiatan ini diawali dengan sambutan pembukaan, dilanjutkan dengan Introduction dan penyampaian materi laporan keuangan atau financial report berdasarkan SAK ETAP serta dilanjutkan dengan pelatihan pencatatan dengan menggunakan Excel. Materi yang disiapkan pada pelatihan ini meliputi proses penyusunan laporan keuangan yaitu pembuatan jurnal, buku besar, laporan neraca, laporan Sisa Hasil Usaha dan laporan arus kas. Kegiatan pelatihan ini dilaksanakan pada tgl 11-12 Mei, bertempat di kediaman salah satu pengurus koperasi. Kegiatan pelatihan ini terdiri dari tiga tahapan yang meliputi pemberian materi, diskusi dan praktik penyusunan laporan keuangan (Financial Report). Pemberian materi pelatihan ini berlangsung selama 5 jam. Materi yang disampaikan antara lain penyusunan jurnal, posting jurnal ke Buku Besar, Laporan Sisa Hasil Usaha, Neraca dan Laporan arus kas. Setelah penyampain materi, kemudian dilanjutkan dengan diskusi yang berlangsung dengan tertib dan terarah. Pada saat diskusi peserta berperan aktif bertanya terkait dengan permasalahan yang mereka hadapi dalam pengelolaan koperasi. Adapun pertanyaan tersebut dapat dilihat pada Tabel 1 berikut ini:

Tabel 1. Daftar Pertanyaan Peserta

\begin{tabular}{|c|c|c|}
\hline No & Nama & Pertanyaan \\
\hline 1 & Sri Haryanti & Apakah non anggota koperasi boleh mengajukan pinjaman? \\
\hline 2 & Sigit Harjanto & $\begin{array}{l}\text { Apakah pengurus mendapatkan upah atas jasa dan penggantian } \\
\text { biaya operasional mereka? }\end{array}$ \\
\hline 3 & Hastin Ambarwati & $\begin{array}{l}\text { Apakah koperasi akan terus didampingi dan dibina oleh Tim } \\
\text { Dosen Universitas Budi Luhur? }\end{array}$ \\
\hline 4 & Sulasmi & $\begin{array}{l}\text { Kapan Financial Report berdasarkan SAK ETAP dapat } \\
\text { diterapkan? }\end{array}$ \\
\hline 5 & Sukamto \& Umiyatun & $\begin{array}{l}\text { Kapan Financial Report berdasarkan SAK ETAP dapat } \\
\text { diterapkan? }\end{array}$ \\
\hline
\end{tabular}

Analisis Kesesuaian Penyajian Laporan Keuangan Koperasi Serba Usaha Mandiri terhadap Penerapan SAK ETAP tentang ruang lingkup, berdasarkan ketetapan ini, dapat disimpulkan bahwa ada dua syarat penting bagi suatu entitas agar dapat menjadikan SAK ETAP sebagai dasar akuntansi yang diterapkan dalam laporan keuangan yang akan disajikan, yaitu mengenai akuntabilitas publik dan tujuan penerbitan laporan keuangan. Koperasi Serba Usaha Mandiri telah menjalankan kegiatan intermediasi dana dengan mengumpulkan dana dari seluruh anggota koperasi dalam bentuk simpanan untuk kembali didistribusikan kepada anggota yang membutuhkan dana dalam bentuk pinjaman. Berdasarkan hal ini terlihat jelas bahwa Koperasi tersebut memiliki akuntabilitas publik yang signifikan, tetapi karena koperasi tersebut belum mendaftarkan diri sebagai perusahaan publik, maka Koperasi Serba Usaha Mandiri hanya bertanggung jawab atas dana anggotaanggotanya. Berdasarkan penjelasan di atas terlihat bahwa fakta-fakta yang ada terkait Koperasi mendukung 
bahwa Koperasi Serba Usaha Mandiri dapat menggunakan SAK ETAP sebagai standar akuntansinya. Setelah melakukan pengumpulan data terkait catatan akuntansi dan laporan keuangan yang sudah berlangsung di koperasi ini, tim pengabdian masyarakat menganalisis kesesuaian penerapan Standar Akuntansi Keuangan Tanpa Akuntabilitas Publik (SAK ETAP) yang dilakukan oleh koperasi Serba Usaha Mandiri. Berdasarkan hasil analisis atas penyajian Laporan Keuangan Koperasi ternyata Koperasi Serba Usaha Mandiri belum menaati ketentuan ini dengan melaksanakan pencatatan dan penyajian laporan akuntansi yang sesuai dengan SAK ETAP. Dalam membuat laporan keuangan pengurus Koperasi masih menggunakan cara konvensional, yaitu menggunakan pencatatan secara manual dan pembukuan yang dilakukan masih sangat sederhana. Sedangkan dalam kaitannya dengan penerapan SAK ETAP secara penuh dalam SAK ETAP paragraf 3.12 dan 3.9 menyatakan bahwa laporan keuangan entitas meliputi Neraca, Laporan Laba Rugi, Laporan Perubahan Ekuitas, Laporan Arus Kas, dan Catatan Atas Laporan Keuangan yang harus diungkapkan secara komparatif dengan periode sebelumnya. Berikut akan disajikan pada Tabel 2 untuk membandingkan penerapan ketentuan SAK ETAP pada laporan keuangan Koperasi Serba Usaha Mandiri. Pembahasan mencakup berbagai aturan yang ditetapkan dalam SAK ETAP termasuk mengenai konsep, prinsip, pengakuan, pengukuran serta penyajian laporan keuangan yang dibuat oleh Koperasi Serba Usaha Mandiri Desa Manisrenggo, Klaten.

Tabel 2. Penerapan Ketentuan SAK ETAP

\begin{tabular}{|c|c|c|}
\hline Ketentuan Sesuai SAK ETAP & Iya/Tidak & Keterangan \\
\hline Double entry accounting system & Tidak & $\begin{array}{l}\text { Masih menggunakan single entry accounting } \\
\text { system }\end{array}$ \\
\hline Dasar akrual & Tidak & Menggunakan dasar kas (cash basis) \\
\hline $\begin{array}{l}\text { Frekuensi pelaporan (minimum satu tahun } \\
\text { sekali) }\end{array}$ & Iya & $\begin{array}{l}\text { Informasi Keuangan yang disajikan hanya } \\
\text { pada periode pelaporan saja }\end{array}$ \\
\hline Informasi komparatif & Tidak & $\begin{array}{l}\text { Karena menggunakan cash basis informasi } \\
\text { keuangan hanya menyajikan mutasi saldo } \\
\text { tabungan, dan selisihnya diakui sebagai } \\
\text { pembagian SHU (Sisa Hasil Usaha) }\end{array}$ \\
\hline
\end{tabular}

Penyajian Laporan Keuangan Lengkap meliputi: neraca, laporan laba rugi atau SHU, laporan perubahan ekuitas, laporan arus kas

Tidak dan catatan atas laporan keuangan

\section{KESIMPULAN}

Setelah mengikuti pelatihan system akuntansi koperasi baik secara manual maupun dengan menggunakan Excel, para pengurus koperasi Serba Usaha Mandiri Desa Manisrenggo-Klaten telah bertambah pemahamannya tentang pentingnya penerapan SAK ETAP bagi penyajian laporan keuangan Koperasi. Peningkatan pemahaman para pengurus koperasi mengenai konsep dan prinsip dasar akuntansi perkoperasian, unsur-unsur pengakuan, pengukuran dan penyajian laporan keuangan yang sesuai dengan SAK ETAP, maka dapat membantu mereka dalam proses penyusunan dan penyajian laporan keuangan pada periode yang akan datang. Kegiatan pengabdian kepada masyarakat ini menjadi tahap awal dalam proses penerapan akuntansi koperasi sesuai dengan SAK ETAP, yang selanjutnya akan dikembangkan dengan pembuatan system akuntansi untuk koperasi. Pelatihan sistem akuntansi koperasi ini, diharapkan dapat menjadi road map untuk periode yang akan datang, sehingga dapat dibuatkan system akuntansinya supaya lebih membantu tim pengurus koperasi dalam menjalankan tugasnya dan mempermudah penyimpanan file-file anggota atau halhal yang bersifat administrasi ataupun keuangan dalam database. Para pengurus Koperasi Serba Usaha Mandiri hendaknya terus belajar untuk dapat memahami dan menerapkan akuntansi koperasi yang sesuai dengan SAK ETAP baik secara manual maupun menggunakan Excel. Penerapannya dapat dilakukan secara konsisten dan berkesinambungan, sehingga laporan keuangan yang dihasilkan dapat dijadikan sebagai dasar yang tepat dalam menilai kinerja dan pengambilan keputusan. 


\section{DAFTAR PUSTAKA}

Adiputra, I Made Sujana, Sinarwati, Ni Kadek dan Purnamawati, Gusti Ayu. 2017. Pengaruh Pemahaman Akuntansi Berbasis Sak-Etap, Kualitas Pelatihan, Dan Sistem Pengendalian Internal Terhadap Kualitas Laporan Keuangan Koperasi (Studi Empiris Pada Koperasi Simpan Pinjam di Kecamatan Karangasem). e-Journal S1 Akuntansi Universitas Pendidikan Ganesha, 8(2).

Aji Basuki Rohmat. 2015. Analisis Penerapan Prinsip-Prinsip Koperasi Dalam Undang-Undang Koperasi (Studi Undang-Undang No. 25 Tahun 1992 dan Undang-Undang No.17 Tahun 2012) Jurnal Pembaharuan Hukum Volume II No. 1 Januari - April 2015.

Eva Malina Simatupang1, Arlina Pratiwi Purba. 2018. Analisis Penerapan Sak Etap Dalam Penyajian Laporan Keuangan Pada Koperasi Pegawai Negeri Smpn 7 Pematang Siantar. Jurnal Akuntansi Barelang, 3(1).

Mustangin, Nufa Pramina Islami, Desy Kusniawati, Baruna Setyaningrum, Eni Prasetyawati. 2018. Hasil Pemberdayaan Masyarakat Oleh Koperasi Sebagai Upaya Mewujudkan Kesejahteraan Masyarakat Petani Daerah Cepogo. Social Work Jurnal, 8(1), 46-54. https://doi.org/10.24198/share.v8i1.16343

Norkamsiah, Agus Iwan Kesuma, Agus Setiawaty. 2016. Penerapan Standar Akuntansi Keuangan Entitas Tanpa Akuntabilitas Publik (Sak Etap) Pada Penyusunan Laporan Keuangan. Jurnal Ekonomi dan keuangan, 13(2), 151. http://journal.feb.unmul.ac.id

Nurul Mahmudah, Hetika. 2017. Penerapan Akuntansi Dan Kesesuaiannya Dengan Sak Etap Pada Umkm Kota Tegal. Jurnal Akuntansi, Ekonomi dan Manajemen Bisnis Article History, 5(2), 259-266.

Novrina Chandrasukartini. 2015. Rancangan Pembukuan Akuntansi Berbasis Excel For Accounting Pada Koperasi Jasa Keuangan Syariah (KJKS). Jurnal Akuntansi \& Manajemen, 10(1), 13-24.

Rifkaliana Jimmy Berlian Dwi Iga Luhsari Bambang Ismanto. 2020. SAK ETAP: Evaluasi Laporan Keuangan Koperasi Unit Desa. Jurnal Riset Akuntansi dan Perpajakan. https://doi.org/10.35814/jrap.v7i01.1414

Romney, Marshall B., and Paul John Steinbart. 2015. Accounting Information Systems, $13^{\text {th }}$ edt. New Jersey: Pearson Education Inc.

Tedi Rustendi. 2019. Aplikasi Sistem Pdeberbasis Exceluntuk Akuntansi Keuangan Organisasi Nir-Laba. Jurnal Pengabdian Siliwangi, 5(1).

Yusmaniarti, Sri Ekowati. Laporan Keuangan Koperasi Berbasis Media Excel For Accounting. www.jurnal.umb.ac.id 